\title{
Species-specific DNA markers for identification of two root-knot nematodes of coffee: Meloidogyne arabicida and M. izalcoensis
}

\author{
Valdir Ribeiro Correa • Marcilene Fernandes Almeida dos Santos • \\ Maria Ritta Alves Almeida • José Ricardo Peixoto • Philippe Castagnone-Sereno • \\ Regina Maria Dechechi Gomes Carneiro
}

Accepted: 14 June 2013 /Published online: 29 June 2013

(C) KNPV 2013

\begin{abstract}
Seven root-knot nematodes (RKN), including Meloidogyne exigua, M. incognita, $M$. paranaensis, $M$. enterolobii, M. arabicida, M. izalcoensis and $M$. arenaria are major pathogens of coffee crop in the Americas. Species-specific primers for their identification have been developed for five of them and constitute a fast and reliable method of identification. Here we report a PCR-based assay for specific detection of $M$. arabicida and M. izalcoensis. Random Amplified Polymorphic DNA fragments specific for these two
\end{abstract}

Valdir Ribeiro Correa and Marcilene Fernandes Almeida dos Santos contributed equally to this work.

V. R. Correa - M. F. A. dos Santos • M. R. A. Almeida • R. M. D. G. Carneiro ( $\bowtie)$

Embrapa Recursos Genéticos e Biotecnologia,

Brasília, DF 70849-970, Brazil

e-mail: regina.carneiro@embrapa.br

\section{R. Correa}

Departamento de Fitopatologia, Universidade de Brasília, Brasília, DF 70910-900, Brazil

M. F. A. dos Santos · J. R. Peixoto

Faculdade de Agronomia \& Medicina Veterinária,

Universidade de Brasília,

Brasília, DF 70910-900, Brazil

P. Castagnone-Sereno

INRA-UMR1355, UNS, CNRS-UMR7254, Institut

Sophia Agrobiotech, 400 route des Chappes

BP167, 06903 Sophia Antipolis, France species were converted into sequence characterized amplified region (SCAR) markers. PCR amplification using the SCAR primers produced a specific fragment of $300 \mathrm{bp}$ and $670 \mathrm{bp}$ for $M$. arabicida and $M$. izalcoensis, respectively, which were absent in other coffee-associated Meloidogyne spp. tested. SCAR primers also allowed successful amplification of DNA from single second-stage juveniles (J2), males and females. In addition, these primers were able to unambiguously detect the target species in nematode suspensions extracted from soil and roots samples, in different isolates of the same species or when used in multiplex PCR reactions containing mixtures of species. These results demonstrated the effectiveness of these SCAR markers and their multiplex use with those previously developed for $M$. exigua, M. incognita, $M$. paranaensis, $M$. enterolobii and $M$. arenaria constitute an essential detection tool. This diagnostic kit will contribute for specific $\mathrm{J} 2$ identification of the major RKN infecting coffee from field samples in the Americas.

Keywords Diagnostic - Identification kit · RAPD-PCR · Multiplex $\cdot$ Molecular technique

\section{Introduction}

Root-knot nematodes (RKN), Meloidogyne spp., are amongst the most economically important plantparasitic nematodes infecting coffee (Coffea spp.) in 
several countries in the Americas, including Brazil, El Salvador, Guatemala, Costa Rica, Hawaii and others (Lopez and Salazar 1989; Campos et al. 1990; Carneiro et al. 1996a, 2004; Hernandez et al. 2004; Campos and Villain 2005; Carneiro et al. 2005b; Villain et al. 2008). From an estimated set of 17 Meloidogyne spp. infecting coffee trees worldwide, seven of these species, including M. exigua Goeldi, M. incognita (Kofoid \& White) Chitwood 1949, M. paranaensis Carneiro et al. 1996a, M. enterolobii Yang and Eisenback 1983, M. arenaria (Neal) Chitwood 1949, M. arabicida Lopez and Salazar 1989 and M. izalcoensis Carneiro et al. 2005a, have been found infecting coffee plants in the Americas with reducing yields and significant economic losses (Campos et al. 1990; Barbosa et al. 2004; Campos and Villain 2005; Villain et al. 2008). Further, some of these species are still restricted to certain areas, e.g. M. enterolobii in Cuba (Rodriguez et al. 1995), Costa Rica and Guatemala (Hernandez et al. 2004; Villain et al. 2008), M. arabicida in Costa Rica and M. izalcoensis in El Salvador (Carneiro and Cofcewicz 2008). M. arabicida causes severe die-back symptoms on coffee crop and is frequently associated with the coffee disease complex known as corky root (Lopez and Salazar 1989). M. izalcoensis is widely distributed in a region of $\mathrm{El}$ Salvador, known as the volcanic massif of Izalco, where it causes substantial plant damage (Carneiro et al. 2005a; Villain et al. 2008).

Considering the recent withdrawal of most chemical nematicides from the market, the most effective means of controlling these nematodes is currently through the use of resistant cultivars. However, accurate and fast identification of nematode species is extremely important not only for breeding programs but also for studying their genetic and biological variability or to avoid global spread of exotic and quarantine pathogens (Skantar and Carta 2005; Blok and Powers 2009). Meloidogyne spp., are highly diverse, genetically, morphologically and biologically, and their identification using classical methods has proven complex, difficult and time-consuming. Furthermore, it can be mistaken in some cases when the perineal patterns have been used as the only criterion (Carneiro and Cofcewicz 2008).

As an alternative, more accessible diagnostic approaches such as isozyme electrophoresis profiling and PCR-based techniques have proven reliable, reproducible and a faster way to monitor and characterize Meloidogyne species, making them attractive identification tools (Esbenshade and Triantaphyllou 1985, 1990; Carneiro et al. 1996b, 2000; Blok and Powers 2009). Accordingly, esterase isozyme electrophoretic profiling is a robust and appropriate method for identifying Meloidogyne spp. from coffee with high accuracy (Carneiro et al. 2000, 2004; Hernandez et al. 2004; Carneiro and Cofcewicz 2008). However, from the 17 RKN species detected on coffee, only 11 have their esterase phenotypes well characterized (Carneiro and Cofcewicz 2008), and unlike esterase phenotyping, PCR-based diagnostic can be used routinely independent of life stages of nematodes. Several PCR-based diagnostic tools have been developed for some of the most common Meloidogyne species and constitute fast, simple and reliable methods of nematode identification. The main approaches include: i) Sequence Characterized Amplified Regions (SCAR markers) obtained from Random Amplified Polymorphic DNA (RAPD) screening and subsequent conversion into species-specific primers, ii) amplification and sequencing of specific ribosomal DNA or mitochondrial DNA fragments, and iii) analysis of neutral markers, e.g. Amplified Fragment Length Polymorphisms (AFLP) (Harris et al. 1990; Cenis 1993; Zijlstra 2000; Zijlstra et al. 2000; Randig et al. 2002; Berry et al. 2008; Blok and Powers 2009; Tigano et al. 2010). In particular, successful SCAR markers have been developed for diagnosing some of the major Meloidogyne spp. associated with coffee trees, including $M$. arenaria (Zijlstra et al. 2000; Meng et al. 2004), M. incognita (Randig et al. 2002; Meng et al. 2004), M. paranaensis, M. exigua (Randig et al. 2002) and M. enterolobii (Tigano et al. 2010). These primers were validated in several population studies, using DNA from a single juvenile (J2), or in multiplex PCR reactions containing mixtures of species, and have become an excellent practical diagnostic kit for coffee-associated Meloidogyne spp. (Randig et al. 2002, 2004; Carneiro et al. 2004, 2005b).

This study describes two new SCAR markers that are species-specific for the diagnosis of $M$. arabicida and M. izalcoensis. In combination with SCAR markers previously described for other species parasitizing coffee trees (Zijlstra et al. 2000; Randig et al. 2002; Tigano et al. 2010), these two new markers may contribute further to diagnosing major coffee RKNs in the Americas, and more generally expand the list of SCAR markers available for identifying Meloidogyne spp. 


\section{Materials and methods}

Nematode populations

A total of 13 populations representing seven Meloidogyne species originating from Brazil (5), Costa Rica (5), El Salvador (2) and Vietnam (1) were used in this study (Table 1). Additionally to the two studied species, $M$. arabicida and M. izalcoensis, we included five other RKN species that are most frequently associated with coffee crop in Latin America. Nematodes were inoculated either on tomato plants (Solanum lycopersicum L. cv. Santa Clara) or on coffee plants (Coffea arabica cv. Mundo Novo) and maintained under greenhouse conditions for ca. 90-180 days. Nematodes were then identified using esterase profiling as previously described (Carneiro and Almeida 2001).

\section{DNA extraction}

Nematode eggs were extracted from infected roots of tomato and coffee plants according to a modified protocol (Carneiro et al. 2004), originally described by McClure et al. (1973), and stored at $-80{ }^{\circ} \mathrm{C}$. For each nematode isolate, total genomic DNA was extracted from ca. 200$300 \mu \mathrm{l}$ of eggs. Briefly, eggs were macerated in liquid nitrogen with a pestle and mortar, and DNA was extracted from the resulting powder according to procedures described in Randig et al. (2002). Isolated DNA was treated with RibonucleaseA (10 mg/ml) (Sigma-Aldrich, São Paulo, Brazil) and quantified in a $1 \%$ agarose gel.
Genomic DNA was also extracted from individual nematodes, including females, males and second stage juveniles (J2), using a modified protocol originally described by Holterman et al. (2006). Individual eggmasses were handpicked and placed on a modified Baermann funnel for hatching. A single $\mathrm{J} 2$ or male was then picked and transferred into a $0.2 \mathrm{ml}$ PCR tube containing $25 \mu \mathrm{l}$ of sterile deionized water. An equal volume of lysis buffer [0.2 M NaCl, $0.2 \mathrm{M}$ Tris- $\mathrm{HCl}$ $\mathrm{pH} 8,1 \%(\mathrm{v} / \mathrm{v}) \beta$-mercaptoethanol and $880 \mu \mathrm{g} / \mathrm{ml}$ of proteinase $\mathrm{K}$ ] was added into each tube and maintained at $4{ }^{\circ} \mathrm{C}$. Single females were handpicked under a dissecting microscope $\left(\right.$ Leica $\left.^{\circledR}\right)$ using a fine-tipped forceps and transferred into a 2-ml tube containing $25 \mu \mathrm{l}$ of sterile water. An equal volume of cold lysis buffer was added to each tube and the female was macerated with a mini plastic pestle. Individual nematode samples were incubated on a PTC-100 MJ Research thermocycler (MJ Research Inc ${ }^{\circledR}$, Waltham-MA, USA) at $65^{\circ} \mathrm{C}$ for $2 \mathrm{~h}$, followed by $10 \mathrm{~min}$. incubation at $95^{\circ} \mathrm{C}$ and a final hold at $4{ }^{\circ} \mathrm{C}$. Lysates were centrifuged at $1 \times \mathrm{g}$ for $2 \mathrm{~min}$. at $4{ }^{\circ} \mathrm{C}$ and diluted at $4: 1(\mathrm{v} / \mathrm{v})$ with sterile water. Lysates were aliquoted and stored at $-20{ }^{\circ} \mathrm{C}$. One to three microlitres of lysates were used for PCR analysis.

RAPD analysis

RAPD-PCR analysis was performed in a $25 \mu$ final volume, containing 1X PCR reaction buffer (Phoneutria Biotecnologia \& Serviços-pht ${ }^{\circledR}$, São Paulo, Brazil), $200 \mu \mathrm{M}$ of each dNTP (dATP, dTTP, dGTP and dCTP)
Table 1 List of Meloidogyne spp., populations used in this study

a exi (1 and 2): virulent and avirulent isolates of $M$. exigua, inc (1 and 2): races 1 and 3 of $M$. incognita

\begin{tabular}{|c|c|c|c|}
\hline Species & Code & Origin & Original host species \\
\hline \multirow[t]{4}{*}{ M. arabicida } & ara-1 & Turrialba, Costa Rica & Coffea arabica \\
\hline & ara-2 & Juan Viñas, Costa Rica- site A & C. arabica \\
\hline & ara-3 & Espirito Santo, Costa Rica & C. arabica \\
\hline & ara-4 & Juan Viñas, Costa Rica- site B & C. arabica \\
\hline \multirow[t]{2}{*}{ M. izalcoensis } & iza-1 & El Salvador & C. arabica \\
\hline & iza-2 & Vietnam & Musa sp. \\
\hline M. arenaria & are & El Salvador & C. arabica \\
\hline \multirow[t]{2}{*}{ M. exigua ${ }^{\mathrm{a}}$} & exi-1 & Lavras, MG, Brazil & C. arabica \\
\hline & exi-2 & Bom Jesus da Itabapoara, RJ, Brazil & C. arabica \\
\hline \multirow[t]{2}{*}{ M. incognita $^{\mathrm{a}}$} & inc-1 & Londrina-PR, Brazil & C. arabica \\
\hline & inc-2 & Avilândia, SP, Brazil & C. arabica \\
\hline M. enterolobii & ent & Turrialba, Costa Rica & C. arabica \\
\hline M. paranaensis & par & Londrina, PR, Brazil & C. arabica \\
\hline
\end{tabular}


(Invitrogen ${ }^{\circledR}$, São Paulo, Brazil), $10 \mu \mathrm{M}$ of primer (Operon Technologies, Alameda-Ca, USA), 1U of Taq DNA polymerase $\left(\mathrm{pht}^{\circledR}\right)$ and 6 ng of total genomic DNA from $M$. arabicida, M. izalcoensis and the outgroup control species (Table 1). Reaction mixtures were overlaid with a drop of mineral oil. Amplifications were performed on a PTC-100 MJ Research thermal cycler with the following cycling conditions: $5 \mathrm{~min}$ at $94{ }^{\circ} \mathrm{C}$; 40 cycles of $30 \mathrm{~s}$ at $94{ }^{\circ} \mathrm{C}, 45 \mathrm{~s}$ at $36^{\circ} \mathrm{C}, 2 \mathrm{~min}$ at $70{ }^{\circ} \mathrm{C}$ and a final extension of $10 \mathrm{~min}$ at $70{ }^{\circ} \mathrm{C}$ (Randig et al. 2002). A total of thirty-nine random 10 -mer oligonucleotide primers were used in the experiments (Operon Technologies, primers OPA4, OPA7, OPA12, OPA18, OPB3, OPB4, OPB6, OPB7, OPB9, OPB11, OPB12, OPAB2, OPAB6, OPC2, OPD5, OPD13, OPF6, OPG2, OPG3, OPG4, OPG5, OPG13, OPJ10, OPJ20, OPK1, OPK9, OPK16, OPK10, OPK14, OPK20, OPM10, OPM20, OPN7, OPP1, OPP5, OPQ12, OPR3, OPR4 and OPR8. Amplification products were separated by electrophoresis in a $1.5 \%(\mathrm{w} / \mathrm{v})$ agarose gel in Tris Borate EDTA buffer ( $89 \mathrm{mM}$ Tris-HCl, $89 \mathrm{mM}$ Borate, $2 \mathrm{mM}$ EDTA) at a constant current of $100 \mathrm{~mA}$ for approximately $4 \mathrm{~h}$, stained with ethidium bromide solution $(0.3 \mu \mathrm{g} / \mathrm{ml})$ and visualized under UV light. The experiments were repeated three times.

\section{Development of SCAR markers}

RAPD bands present only in M. arabicida or in $M$. izalcoensis were selected, excised from the agarose gel using the Wizard ${ }^{\circledR}$ SV Gel and PCR Clean Up System (Promega, São Paulo, Brazil), and cloned into the pGEM-T ${ }^{\circledR}$ Easy vector (Promega, Inc ${ }^{\circledR}$.), according to the manufacturer's instructions. For each fragment cloned, sequencing of the insert was carried out on two independent clones by Macrogen (Seoul, South Korea). From each sequence obtained, a pair of species-specific primers with higher annealing temperature (Tm) and high $\mathrm{G}+\mathrm{C}$ content was designed based on the consensus sequences using the PRIMER3 v.4.0 software (Rozen and Skaletsky 2000) and synthesized by Sigma-Aldrich ${ }^{\circledR}$. Specific SCAR primer sequences of 20-24 base pairs were designed spanning the RAPD primer sequences (Table 2).

\section{SCAR analysis}

Reaction mixtures for SCAR-PCR were the same as those described for RAPD analysis. Amplifications were performed on a PTC-100 MJ Research thermal cycler with the following cycling conditions for M. arabicida (primers ar-A12F/R): $5 \mathrm{~min}$ at $94{ }^{\circ} \mathrm{C}$ followed by 30 cycles of $30 \mathrm{~s}$ at $94{ }^{\circ} \mathrm{C}, 45 \mathrm{~s}$ at $64{ }^{\circ} \mathrm{C}$, $1 \mathrm{~min}$ at $70^{\circ} \mathrm{C}$ and a final extension of $8 \mathrm{~min}$ at $70^{\circ} \mathrm{C}$. Cycling conditions for $M$. izalcoensis (primers iz$\mathrm{AB} 2 \mathrm{~F} / \mathrm{R}$ ) were the same as those described for $M$. arabicida, except that the annealing temperature was $67{ }^{\circ} \mathrm{C}$.

The specificity and reliability of SCAR markers developed in this study for M. arabicida (ar-A12F/R) and for $M$. izalcoensis (iz-AB2F/R) (Table 2) were tested with four isolates of M. arabicida and two isolates of $M$. izalcoensis against isolates of five frequent on coffee RKN species (Table 1). Reaction conditions of SCAR-PCR using single nematodes (second stage infective juveniles, males and females) were the same as described above for the two nematode species, except that a total of 40 cycles and double volume of the Taq DNA polymerase were used. Amplification products were resolved in a $1 \%$ agarose gel, stained with ethidium bromide solution $(0.3 \mu \mathrm{g} / \mathrm{ml})$ and visualized under UV light. The experiments were repeated at least three times.

Since some of these species are found in mixtures under natural infection, we performed SCAR analyses (individually or in multiplex) of other Meloidogyne spp., infecting coffee, including $M$. incognita, M. exigua and $M$. paranaensis using purified DNA from eggs or DNA extracts from single individual according to Randig et al. (2002). Multiplex SCAR-PCR of $M$. arabicida plus $M$. exigua mixture was done using the same conditions as described for M. arabicida, using $10 \mu \mathrm{M}$ of each primer pair (ar-A12F/R and ex-D15F/R) and $6 \mathrm{ng}$ of purified DNA from eggs or DNA extract from single individual for each species. SCAR analysis of M. enterolobii was done according to Tigano et al. (2010) with the following modifications: the reaction was performed in a $25 \mu$ volume, containing $1 \mathrm{X}$ reaction buffer $\left(\mathrm{pht}^{\circledR}\right)$, $200 \mu \mathrm{M}$ of each dNTPs (Invitrogen), $10 \mu \mathrm{M}$ of each forward and reverse primers (Life Technologies) (Table 2), 1U of Taq DNA polymerase $\left(\mathrm{pht}^{\circledR}\right)$ and $6 \mathrm{ng}$ of total genomic DNA. PCR cycling consisted of $5 \mathrm{~min}$ at $94^{\circ} \mathrm{C}$, followed by 25 cycles of $30 \mathrm{~s}$ at $94^{\circ} \mathrm{C}$, $40 \mathrm{~s}$ at $74^{\circ} \mathrm{C}, 1 \mathrm{~min}$ at $70^{\circ} \mathrm{C}$ and a final extension of 8 min at $70^{\circ} \mathrm{C}$. Amplification products were analyzed as described above. The experiments were repeated at least three times. 
Table 2 Characteristics of SCAR markers developed for Meloidogyne spp. associated with coffee

\begin{tabular}{|c|c|c|c|c|}
\hline Species & Name of SCAR primers & Sequences $\left(5^{\prime} \rightarrow 3^{\prime}\right)$ & Size of SCAR (bp) & Reference \\
\hline M. arabicida & $\begin{array}{l}\text { ar-A12F } \\
\text { ar-A12R }\end{array}$ & $\begin{array}{l}\text { TCGGCGATAGTACGTATTTAGCG } \\
\text { TAGTGATTTCGGCGATAGGC }\end{array}$ & 300 & This study \\
\hline M. izalcoensis & $\begin{array}{l}\text { iz-AB2F } \\
\text { iz-AB2R }\end{array}$ & $\begin{array}{l}\text { GGAAACCCCTAATTAGGATACACT } \\
\text { CGCTTGATTTGAGCAGTAGG }\end{array}$ & 670 & This study \\
\hline M. exigua & $\begin{array}{l}\text { ex-D15F } \\
\text { ex-D15R }\end{array}$ & $\begin{array}{l}\text { CATCCGTGCTGTAGCTGCGAG } \\
\text { CTCCGTGGGAAGAAAGACTG }\end{array}$ & 562 & Randig et al. 2002 \\
\hline M. incognita & $\begin{array}{l}\text { inc-K15F } \\
\text { inc-k15R }\end{array}$ & $\begin{array}{l}\text { GGGATGTGTAAATGCTCCTG } \\
\text { CCCGCTACACCCTCAACTTC }\end{array}$ & 399 & Randig et al. 2002 \\
\hline M. paranaensis & $\begin{array}{l}\text { par-C09F } \\
\text { par-C09R }\end{array}$ & $\begin{array}{l}\text { GCCCGA CTCCATTTGA CGGA } \\
\text { CCGTCCAGATCCATCGAAGTC }\end{array}$ & 208 & Randig et al. 2002 \\
\hline M. enterolobii & $\begin{array}{l}\text { MK7F } \\
\text { MK7R }\end{array}$ & $\begin{array}{l}\text { GATCAGAGGCGGGCGCATTGCGA } \\
\text { CGAACTCGCTCGAACTCGAC }\end{array}$ & 520 & Tigano et al. 2010 \\
\hline
\end{tabular}

\section{Results}

Characterization of Meloidogyne spp. populations

All thirteen populations of Meloidogyne spp. used in this study were characterized to species level using esterase (EST) isozyme according to Carneiro et al. (2004, 2005a) and Carneiro and Cofcewicz (2008). These species showed typical EST phenotypes as described: $M$. enterolobii (EST M2, Rm: 0.7, 0.9), M. paranaensis (EST P1, Rm: 1.3), M. incognita (EST I1, Rm: 1.0), M. arenaria (EST A2, Rm: 1.2, 1.3), M. exigua (EST E1, Rm: 1.5), M. izalcoensis (EST I4, Rm: 0.86, 0.96, 1.24, 1.30) and M. arabicida (EST AR2, Rm: 1.20, 1.40). Some populations of $M$. arabicida (isolates ara-2, ara-3 and ara-4) showed mixed infection with $M$. exigua, when diagnosed using EST analysis (not shown).

\section{RAPD screening}

Initially, we screened for polymorphism in M. arabicida, M. izalcoensis and other Meloidogyne species using a total of thirty-nine10-mer RAPD primers (results not shown). This resulted in a total of five candidate markers (i.e., species-specific) for each of the target species, $M$. arabicida (OPA7, OPA12, OPK10, OPK16 and OPP1) and M. izalcoensis (OPA7, OPB11, OPAB2, OPK14 and OPQ12), respectively. These sequences were then converted into species-specific SCAR marker. BLAST search against the NCBI databases (http:// blast.ncbi.nlm.nih.gov) using these marker sequences resulted in no significant similarity to any sequences deposited in the database (results not shown).
Analysis of SCAR markers specific for M. arabicida and M. izalcoensis

From an initial analysis with the five SCAR markers developed for both species (M. arabicida and $M$. izalcoensis), we selected one primer pair for each species for further analyses. Primers ar-A12F/R and iz-AB2F/R (Table 2) were tested with SCAR-PCR reactions and produced a single amplicon of $\sim 300 \mathrm{bp}$ or $670 \mathrm{bp}$ for M. arabicida or M. izalcoensis, respectively, in comparison with other Meloidogyne spp. controls tested (Fig. 1a, b). DNA sequencing of these markers resulted in the same original sequences of the cloned fragments. The specificity and reliability of these primers were also tested against four isolates of M. arabicida and two isolates of M. izalcoensis, and results revealed amplification of DNA at the expected sizes (Fig. 2a, b). In addition, primer ar-A12F/R successfully amplified a single fragment in $M$. arabicida populations (ara-2, ara-3 and ara-4) that had mixed infection with $M$. exigua (Fig. 2a). These primers were also successful in amplifying DNA from single $\mathrm{J} 2$, females and males from both species (Fig. 3a, b). Finally, primer ar-A12F/R (developed for M. arabicida) was tested in a multiplex PCR reaction containing mixtures of DNA 1:1 (v/v) (M. arabicida + M. exigua), and it successfully amplified the expected fragments for the two species (Fig. 4). As an illustration of SCAR markers available for diagnosing major RKNs associated with coffee in Latin America, we also performed SCAR-PCR (individually or in multiplex) for $M$. exigua, $M$. paranaensis, M. incognita and M. enterolobii (Fig. 4). Other combination of multiplex PCR was not performed 
Fig. 1 PCR amplification patterns for nine populations of Meloidogyne spp. generated with specific SCAR primers ar-A12F/R (a), and iz-AB2F/R (b), respectively. are: $M$. arenaria, ara-1: $M$. arabicida, exi-1 and 2: $M$. exigua (virulent and avirulent isolates), inc-1 and 2: M. incognita (races 1 and 3), iza-1: M. izalcoensis, ent: $M$. enterolobii and par: $M$. paranaensis. (-) DNA: negative control. M: $1 \mathrm{~kb}$ Plus DNA ladder. Amplifications were done using bulk DNA purified from eggs

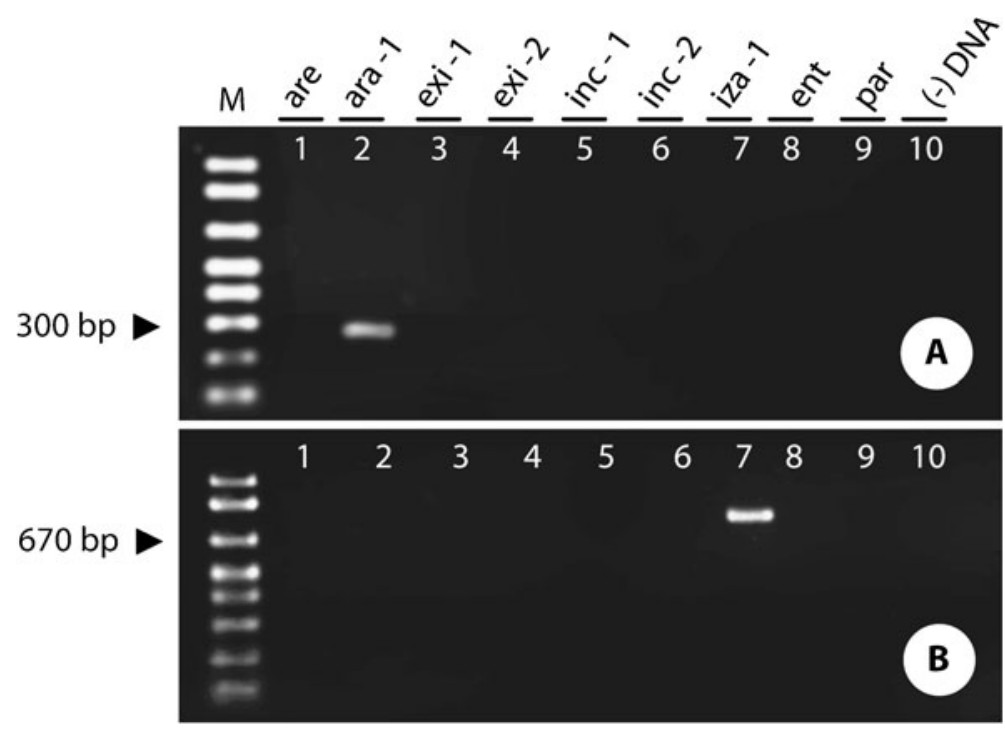

since these species are the ones most frequently found together in the field.

\section{Discussion}

In this study, we successfully developed SCAR markers that can be used for specific diagnosis of M. arabicida and M. izalcoensis. The specificity of these markers was validated by analyzing a total of 13 populations from seven RKN species associated with coffee in different geographic locations, including Brazil and Central America. They were also validated using DNA from single individuals, including $\mathrm{J} 2$, male and female, from nematode suspensions extracted from field samples containing mixtures of species, e.g. M. arabicida $+M$. exigua or in combined DNA mixtures containing species most frequently found together in coffee field. In the multiplex approach only species that were known to concomitantly occur in the field were mixed, such as: $M$. paranaensis, $M$. incognita and $M$. exigua in Brazil (Carneiro et al. 2005b) and M. arabicida and M. exigua detected recently in Juan Viñas and Espirito Santo, Costa Rica (R.M.D.G. Carneiro pers. comm.). Thus, these two new SCAR markers represent an additional molecular tool that can broaden the range of RKN species which can be routinely diagnosed using PCRbased SCAR approaches. Field surveys on coffee for these two nematode species are scarce, and to our knowledge, no other isolates of $M$. arabicida and $M$. izalcoesnsis have been detected elsewhere. Nonetheless, the use of a more simple identification method based on PCR may reveal the presence of these two nematode species in more sites throughout Central America. We tested in our study four isolates of M. arabicida and two of M. izalcoensis. However, these isolates are closely

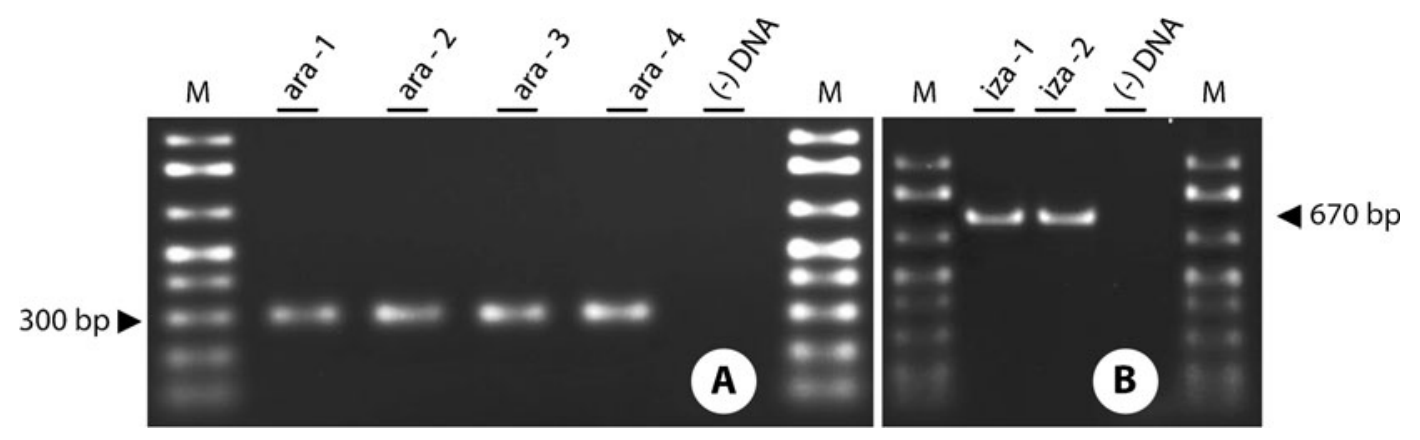

Fig. 2 SCAR-PCR of M. arabicida and M. izalcoensis isolates using purified DNA from eggs. (a) M. arabicida (isolates 1-4) and (b) M. izalcoensis (isolates 1 and 2). Species were tested with primers ar-A12F/R (M. arabicida) and iz-AB2F/R (M. izalcoensis). (-) DNA: negative control. M: $1 \mathrm{~kb}$ Plus DNA ladder 


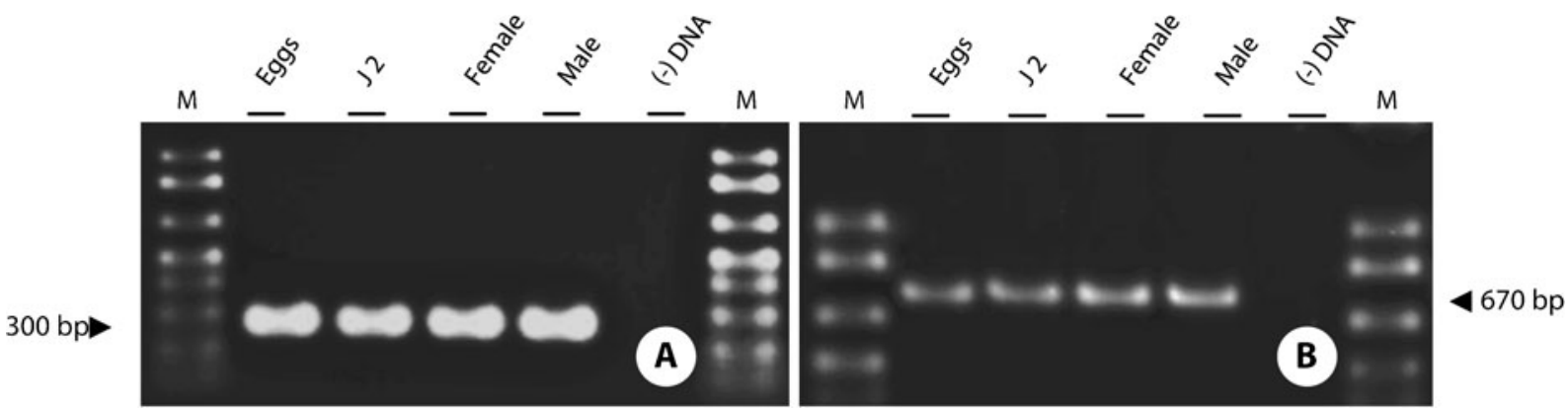

Fig. 3 PCR amplification patterns from single individual second stage juvenile, female and male. (a) M. arabicida (ara-1) was amplified with primer pairs (ar-A12F/R) and (b) $M$.

related according to results reported by Carneiro et al. (2004) and Tigano et al. (2005) who observed that the two isolates of $M$. izalcoensis and two of $M$. arabicida are phylogenetically closely related as revealed by RAPD-PCR or using ribosomal and mitochondrial DNA sequences, respectively. These results indicate that these markers are conserved within isolates for these two nematode species. In addition, further surveys in coffee plants must be done in Central and South America to validate these two primers in field conditions, like the survey carried out by Carneiro et al. (2005b), that validated the SCAR kit previously developed for Brazilian RKN populations detected on coffee (Randig et al. 2002). izalcoensis (iza-1) with (iz-AB2F/R). M: 1 kb Plus DNA ladder. (-) DNA: negative control

SCAR markers have also been developed for other RKNs often associated with coffee in the Americas, including M. arenaria (Zijlstra et al. 2000), M. incognita (Randig et al. 2002; Meng et al. 2004), M. paranaensis, M. exigua (Randig et al. 2002) and M. enterolobii (Tigano et al. 2010). Together with the SCAR markers developed in this study, these seven SCAR markers form an excellent diagnostic kit that can routinely be used to monitor the main species of RKNs infesting coffee in Latin America. While esterase isozyme phenotypes are restricted in characterizing females of Meloidogyne species (Carneiro and Cofcewicz 2008), PCR-based methods are more suitable for routine diagnosis. PCR is fast, can be used in a large number of samples and can detect single

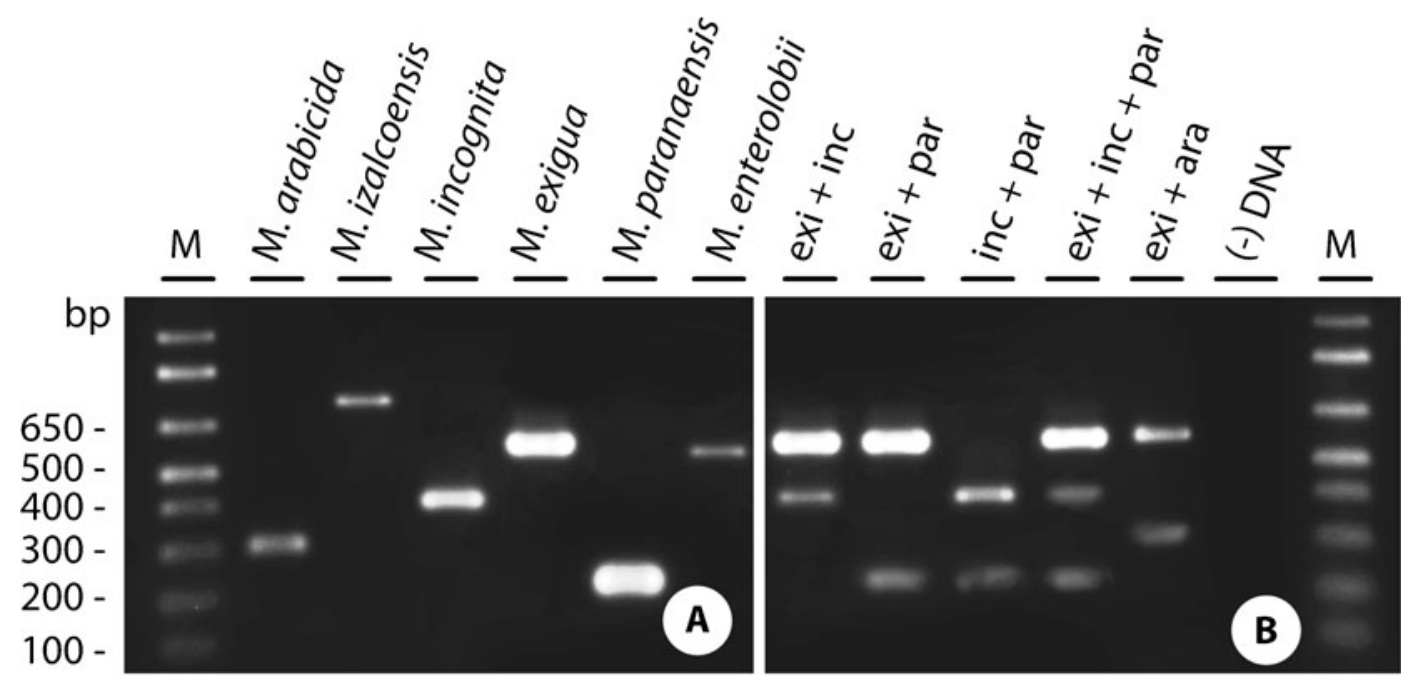

Fig. 4 Individual (a) and multiplex (b) SCAR-PCR amplification patterns for Meloidogyne spp. infecting coffee plants. $M$. arabicida (ara-1), M. izalcoensis (iza-1), M. incognita (inc-1), M. exigua (exi-1), M. paranaensis (par) and M. enterolobii (ent). (-) DNA: negative control. $\mathrm{M}=1 \mathrm{~kb}$ Plus DNA ladder. PCR reactions were done using bulk DNA purified from eggs. Individual PCR was performed with single primer pair. Multiplex PCR was amplified using equal amount of primers and target DNA for each of the combined species 
J2 from field soil samples. It also does not need nematode multiplication on host plant until they reach female adult stages (Esbenshade and Triantaphyllou 1985, 1990; Carneiro et al. 2000; Carneiro and Almeida 2001). However, for atypical forms, Meloidogyne sp., the use of a more integrated approach is suggested for identifying nematode species-i.e. using molecular (esterase profiling and PCR-based tools) and morphological data together (Tautz et al. 2003; Blok and Powers 2009). In summary, we successfully developed two SCAR markers for the specific detection of M. arabicida and M. izalcoensis. Our results not only complement the list of species-specific molecular markers that have been developed for routine diagnosis of Meloidogyne spp. in general but also will contribute for the specific detection of these two nematodes species in their country of origin and other regions throughout Latin America where they might be present. Determining the overall distribution of these important nematodes will contribute for a more effective decision on management strategies to be adopted. In addition, these markers complement the 'coffee diagnostic kit' available for the diagnosis of major RKN nematodes parasitizing coffee crop in the Americas.

Acknowledgments This work was supported by the Brazilian agencies Coordenação de Aperfeiçoamento de Pessoal de Nível Superior (CAPES), Conselho Nacional de Desenvolvimento Científico e Tecnológico (CNPq) and EMBRAPA-Recursos Genéticos e Biotecnologia. V.R. Correa and M.F.A. Santos thank CAPES for their scholarships.

\section{References}

Barbosa, D. H. S. G., Viera, H. D., Souza, R. M., Vianaand, A. P., \& Silca, C. P. (2004). Field estimates of coffee yield losses and damage threshold by Meloidogyne exigua. Nematologia Brasileira, 28, 49-54.

Berry, S. D., Fargette, M., Spaull, V. W., Morand, S., \& Cadet, P. (2008). Detection and quantification of root-knot nematode (Meloidogyne javanica), lesion nematode (Pratylenchus zeae) and dagger nematode (Xiphinema elongatum) parasites of sugarcane using real-time PCR. Molecular and Cellular Probes, 22, 168-176.

Blok, V. C., \& Powers, O. (2009). Biochemical and molecular identification. In R. Perry, M. Moens, \& J. L. Starr (Eds.), Root knot nematodes (pp. 98-118). Cambridge: CABI International.

Campos, V. P., \& Villain, L. (2005). Nematode parasites of coffee and cocoa. In M. Luc, R. Sikora, \& J. Bridge (Eds.), Plant parasitic nematodes in subtropical and tropical agriculture (pp. 529-579). Wallingford: CABI International.

Campos, V. P., Sivapalan, P., \& Gnanapragasam, N. C. (1990). Nematode parasites of coffee, cocoa and tea. In M. Luc, R. A. Sikora, \& J. Bridge (Eds.), Plant parasitic nematodes in subtropical and tropical agriculture (pp. 387-430). Wallingford: CABI International.

Carneiro, R. M. D. G., \& Almeida, M. R. A. (2001). Técnica de eletroforese usada no estudo de enzimas dos nematoides de galhas para identificação de espécies. Nematologia Brasileira, 25, 555-560.

Carneiro, R. M. D. G., \& Cofcewicz, E. T. (2008). The taxonomy of coffee-parasitic root-knot nematodes Meloidogyne spp. In R. M. Souza (Ed.), Plant parasitic nematodes of coffee (pp. 87-122). Dordrecht: Springer.

Carneiro, R. M. D. G., Carneiro, R. G., Abrantes, I. M. O., Santos, M. S. N. A., \& Almeida, M. R. A. (1996a). Meloidogyne paranaensis n. sp. (Nemata: Meloidogynidae), a root-knot nematode parasitizing coffee in Brazil. Journal of Nematology, 28, 177-189.

Carneiro, R. M. D. G., Almeida, M. R. A., \& Carneiro, R. G. (1996b). Enzyme phenotypes of Brazilian isolates of Meloidogyne spp. Fundamental and Applied Nematology, 19, 555-560.

Carneiro, R. M. D. G., Almeida, M. R. A., \& Quénéhervé, P. (2000). Enzyme phenotypes of Meloidogyne spp. isolates. Nematology, 2, 645-654.

Carneiro, R. M. D. G., Tigano, M. S., Randig, O., Almeida, M. R. A., \& Sarah, J. L. (2004). Identification and genetic diversity of Meloidogyne spp. (Tylenchida: Meloidogynidae) on coffee from Brazil, Central America and Hawaii. Nematology, 6, 287-298.

Carneiro, R. M. D. G., Almeida, M. R. A., Gomes, A. C. M. M., \& Hernandez, A. (2005a). Meloidogyne izalcoensis n.sp. (Nematoda: Meloidogynidae), a root-knot nematode parasitizing coffea in El Salvador. Nematology, 7, 819-832.

Carneiro, R. M. D. G., Randig, O., Almeida, M. R. A., \& Gonçalves, W. (2005b). Identificação e caracterização de espécies de Meloidogyne em cafeeiros nos Estados de São Paulo e Minas Gerais através dos fenótipos de esterase e SCAR-multiplex PCR. Nematologia Brasileira, 29, 233-241.

Cenis, J. L. (1993). Identification of four major Meloidogyne spp. by random amplified polymorphic DNA (RAPDPCR). Phytopathology, 83, 76-80.

Esbenshade, P. R., \& Triantaphyllou, A. C. (1985). Identification of major Meloidogyne species employing enzyme phenotypes as differentiating characters. In J. N. Sasser \& C. C. Carter (Eds.), An advanced treatise on Meloidogyne (Biology and control, Vol. I, pp. 135-140). Raleigh: North Carolina State University Graphics.

Esbenshade, P. R., \& Triantaphyllou, A. C. (1990). Isozyme phenotypes for the identification of Meloidogyne species. Journal of Nematology, 22, 10-15.

Harris, T. S., Sandal, L. J., \& Power, T. O. (1990). Identification of single Meloidogyne juveniles by polymerase chain reaction amplification of mitochondrial DNA. Journal of Nematology, 22, 518-524.

Hernandez, A., Fargette, M., \& Sarah, J. L. (2004). Characterization of Meloidogyne spp. (Tylenchida: Meloidogynidae) from 
coffee plantations in Central America and Brazil. Nematology, 6, 193-204.

Holterman, M., Van Der Wurff, A., Van Den Elsen, S., Van Megen, H., Bongers, T., Holovachov, O., et al. (2006). Phylum-wide analysis of SSU rDNA reveals deep phylogenetic relationships among nematodes and accelerated evolution toward crown clades. Molecular Biology and Evolution, 23, 1792-1800.

Lopez, R., \& Salazar, L. (1989). Meloidogyne arabicida sp. n. (Nemata: Heteroderidae) nativo de Costa Rica: um nuevo y severo patógeno del cafeto. Turrialba, 39, 313-323.

McClure, M., Kruk, T. H., \& Migashi, I. (1973). A method for obtaining quantities of clear Meloidogyne eggs. Journal of Nematology, 5, 230.

Meng, Q. P., Long, H., \& Xu, J. H. (2004). PCR assays for rapid and sensitive identification of three major root-knot nematodes, Meloidogyne incognita, $M$. javanica and $M$. arenaria. Acta Phytopathologica Sinica, 34, 204-210.

Randig, O., Bongiovanni, M., Carneiro, R. M. D. G., \& Castagnone-Sereno, P. (2002). Genetic diversity of rootknot nematodes from Brazil and development of SCAR markers specific for the coffee-damaging species. Genome, 45, 862-870.

Randig, O., Carneiro, R. M. D. G., \& Castagnone-Sereno, P. (2004). Identificação das principais especies de Meloidogyne parasitas do cafeeiro no Brasil com marcadores SCAR-CAFÉ em Multiplex-PCR. Nematologia Brasileira, 28, 1-10.

Rodriguez, M. G., Rodriguez, I., \& Sanchez, L. (1995). Especies del genero Meloidogyne que parasitan el cafeto en Cuba. Distribucion geografica y sintomatologia. Revista de Proteccion Vegetal, 10, 123-128.

Rozen, S., \& Skaletsky, H. J. (2000). Primer3 on the WWW for general users and for biologist programmers. In S. Krawetz \& S. Misener (Eds.), Bioinformatics methods and protocols: methods in molecular biology (pp. 365-386). Totowa: Humana Press.

Skantar, A. M., \& Carta, L. K. (2005). Multiple displacement amplification (MDA) of total genomic DNA from Meloidogyne spp. and comparison to crude DNA extracts in PCR of ITS1, 28S D2-D3 rDNA and Hsp90. Nematology, 7, 285-293.

Tautz, D., Arctander, P., Minelli, A., Thomas, R. H., \& Vogler, A. P. (2003). A plea for DNA taxonomy. Trends in Ecology \& Evolution, 18, 70-74.

Tigano, M. S., Carneiro, R. M. D. G., Jeyaprakash, A., Dickson, D. W., \& Adams, B. J. (2005). Phylogeny of Meloidogyne spp. based on $18 \mathrm{~S}$ rDNA and the intergenic region of mitocrondrial DNA sequences. Nematology, 7, 851-862.

Tigano, M. S., Siqueira, K., Castagnone-Sereno, P., Mulet, K., Queiroz, P., Santos, M., et al. (2010). Genetic diversity of the root-knot nematode Meloidogyne enterolobii and development for SCAR marker for this guava-damaging species. Plant Pathology, 59, 1054-1061.

Villain, L., Hernandez, A., \& Anzueto, F. (2008). Central America. In R. M. Souza (Ed.), Plant parasitic nematodes of coffee (pp. 261-275). Dordrecht: Springer.

Yang, B., \& Eisenback, J. D. (1983). Meloidogyne enterolobii n. sp. (Meloidogynidae), a root-knot nematode parasitizing pacara earpod tree in China. Journal of Nematology, 15, 381-391.

Zijlstra, C. (2000). Identification of Meloidogyne chitwoodi, M. fallax and M. hapla based on SCAR-PCR: a powerful way of enabling reliable identification of populations or individuals that share common traits. European Journal of Plant Pathology, 106, 283-290.

Zijlstra, C., Donkers-Venne, D. T. H. M., \& Fargette, M. (2000). Identification of Meloidogyne incognita, M. javanica and $M$. arenaria using sequence characterized amplified regions (SCAR) based PCR assays. Nematology, 2, 847-853. 